\title{
Study on stability of fungal phytase as poultry feed additive
}

\author{
M. Karaman, Y. Gurbuz, E. Ozkose and M.S. Ekinci ${ }^{1}$
}

\author{
Kahramanmaras Sutcu Imam University, Faculty of Agriculture, \\ Department of Animal Science \\ 46060 Kahramanmaras, Turkey
}

(Received 27 October 2003; revised version 12 January 2004; accepted 9 April 2004)

\begin{abstract}
Stability of phytase enzyme from Aspergillus niger against different $\mathrm{pH}$ values and proteases was studied to reveal its potential as poultry feed additive. Phytase enzyme lost approximately 53, 32,66 , and $87 \%$ of its activity at $\mathrm{pH} 1,2,8$, and 9 , respectively, but the enzyme was able to recover full activity at $\mathrm{pH} 5.5$ following $6 \mathrm{~h}$ of exposure at $37^{\circ} \mathrm{C}$ to $\mathrm{pH}$ as low as 3. Pre-treatment of phytase enzyme with saliva for an hour resulted in lose of enzyme activity about $10 \%$, and similarly treatment with proteases caused about $40 \%$ decrease of activity. Addition of phytase enzyme to the low phosphorus containing diets kept the tibia ash content constant. Supplementation of diet with phytase enzyme increased availability of total phosphorus. Phytase supplementation of broiler diets also improved growth and body weights and decreased mortality.
\end{abstract}

KEY WORDS: broiler, phytase, phosphorus, stability

\section{INTRODUCTION}

Phytic acid (myo-inositol hexakiphosphate), or phytate, is a major storage form of phosphorus in plants (Mitchell et al., 1997). Phytate degrading enzymes, phytases (myo-inositol hexakisphosphate phosphohydrolases, EC 3.1.3.8 and 3.1.3.26) are found primarily in microorganisms and plants and catalyse the hydrolysis of the phosphoester bonds of phytic acid to liberate inorganic phosphate (Wodzinski and Ullah, 1996). Since monogastric animals (fish, pigs and poultry) virtually lack phytase activity in their digestive tract, phytic acid phosphorus is

\footnotetext{
${ }^{1}$ Corresponding author: e-mail: sekinci@ksu.edu.tr
} 
metabolically unavailable to these animals, necessitating supplementation of the feed with inorganic phosphate (Wodzinski and Ullah, 1996; Pandey et al., 2001). Nearly all the phytate phosphorus ingested by these animals is excreted in the manure, causing environmental phosphorus pollution in areas of intensive livestock production (Bedford, 2000; Mullaney et al., 2000). These problems can be circumvented by supplementation of the feed with a naturally and a recombinantly produced phytase that has a stability to digestive tract enzymes and has a $\mathrm{pH}$ activity profile ideally suited for maximal activity in the digestive tract of monogastric animals (Wodzinski and Ullah, 1996; Pandey et al., 2001).

Phytase activity has been detected in a variety of microbial sources other than Aspergillus species like Bacillus sp., Escherichia coli, ruminal bacteria, and Myceliophthora thermophila, however these enzymes are still not available commercially (Shimizu, 1992; Yanke et al., 1998; Pandey et al., 2001; Gargova and Sariyska, 2003). Several commercial fungal-derived phytase preparations are now available. Amongst the earliest and best known is 'Natuphos', produced by a gene derived from Aspergillus niger 3135 (Van Dijck, 1999). Majority of studies are ongoing to identify, purify or clone phytases even more suited to animal feed application than current commercial preparations (Shimizu, 1992; Yanke et al., 1998; Van Dijck, 1999; Wyss et al., 1999; Pandey et al., 2001; Gargova and Sariyska, 2003). There is limited number of work on characteristics such as stability at elevated temperatures and acid stability/activity (to remain stable/active in the monogastric stomach) is particularly noteworthy in this regard. Therefore, in view of its industrial importance, in the present work, it is aimed to study phytase enzyme in many aspects as possible. Including, determination the resistance of the enzyme activities in potential feed additives to gastric and pancreatic proteolytic activity, and to investigate means of enhancing their resistance to proteolytic breakdown and determination the effect of phytase on dietary phosphorus bioavailability and performance of broilers.

\section{MATERIAL AND METHODS}

\section{Measurements of enzymatic activity}

Phytase (Natuphos, BASF) activity was assayed by the method of Bae et al. (1999). One unit of phytase activity was defined as the amount of enzyme capable of releasing one $\mu \mathrm{mol}$ phosphate per min at $37^{\circ} \mathrm{C}$ and at $\mathrm{pH} 5.5$ measuring the absorbance at $700 \mathrm{~nm}$. The optimal $\mathrm{pH}$ of the phytase was determined by the modified method of Engelen et al. (1994) (at $37^{\circ} \mathrm{C} ; n: 3$ ) using buffers of 0.2 $\mathrm{M}$ glycine- $\mathrm{HCl}(\mathrm{pH} 1.0,2.0$ and 2.5), $0.2 \mathrm{M}$ sodium citrate ( $\mathrm{pH} 3.0,4.0,5.0$ and 5.5), and 0.2 $\mathrm{M}$ Tris- $\mathrm{HCl}(\mathrm{pH} 6.0$ and 8.0). To determine the $\mathrm{pH}$ optimum curves, 
purified enzymes were diluted in $10 \mathrm{mM}$ sodium acetate $(\mathrm{pH}$ 5.0). Incubations were started by mixing aliquots of the diluted enzyme with equal volumes of $1 \%$ $(10 \mathrm{mM})$ phytic acid in the buffers mentioned above. To determine $\mathrm{pH}$ stability, incubations were performed using same buffers without substrate for $6 \mathrm{~h}$ at $37^{\circ} \mathrm{C}$, followed by adjustment to $\mathrm{pH} 5.5$ by the addition of predetermined volumes of $\mathrm{NaOH}$ and incubation for a further 20 min with substrate before measurement of reducing phosphate release.

\section{Experimental birds, sampling and measurement of phosphorus}

Three-day-old Hybro broiler chickens were used in the 5 weeks of study. On the first day chickens were randomly divided into ten experimental units of 14 birds each. The chickens of each experimental unit were kept in separate pens, in a room with standard management conditions. A control, which contain standard phosphorus requirement of chickens, and nine experimental diets (Table 1) were randomly allotted to these experimental units in such a way that each diet was given to one experimental unit of 14 chickens with two repeats.

TABLE 1

Experimental diets and their total phosphorus contain

\begin{tabular}{ccc}
\hline Diets $^{1}$ & $\begin{array}{c}\text { Total phosphorus } \\
\%\end{array}$ & $\begin{array}{c}\text { Phytase } \\
\text { IU }\end{array}$ \\
\hline A & 0.35 & 400 \\
B & 0.35 & 800 \\
C & 0.35 & 1200 \\
D & 0.50 & 400 \\
E & 0.50 & 800 \\
F & 0.50 & 1200 \\
G & 0.65 & 400 \\
H & 0.65 & 800 \\
K & 0.65 & 1200 \\
Control & 0.65 & \\
\hline
\end{tabular}

${ }^{1}$ diets with crude protein $523 \mathrm{~g}$, energy $3075 \mathrm{kcal} / \mathrm{kg}$ were prepared according to the National Research Council (NRC, 1994)

Tibia and blood samples of four chickens (selected at random) from each experimental unit were collected after slaughtering the birds at the end of week 5 . Ash and phosphorus from the tibia was determined as described by Ahmad et al. (2000). Phosphorus from faecal samples calculated by method of Edwards (1992) and from blood was measured using 917 Hitachi-Boehringer Manheim autoanalayzer. 
The data on performance, apparent availability of phosphorus, tibia ash percentages and plasma phosphorus were subjected to statistical analysis for completely randomised design. For statistical analysis SPSS version 11 package programme was used.

\section{RESULTS}

\section{Phytase enzyme stability}

Phytase enzyme activity was suppressed by low $\mathrm{pH}$, but inhibition of enzyme activity by low $\mathrm{pH}$ was not irreversible. While enzyme preincubated with buffers at different $\mathrm{pH}$ for $6 \mathrm{~h}$ at $37^{\circ} \mathrm{C}, \mathrm{pH}$ then adjusted to 5.5 and enzyme activity was recovered (Figure 1). Activities at pH 1, 2, 8 and 9 were approximately 47, 68, 34 and 13\% of maximal activity, respectively, but the enzyme was able to recover full activity at $\mathrm{pH}$ 5.5 following $6 \mathrm{~h}$ of exposure at $37^{\circ} \mathrm{C}$ to $\mathrm{pH}$ as low as 3 (Figure 1). Thus any inactivation of enzyme by poultry digestive system $\mathrm{pH}$, while enzyme passes through the each part of digestive organs, is expected to be reversible.

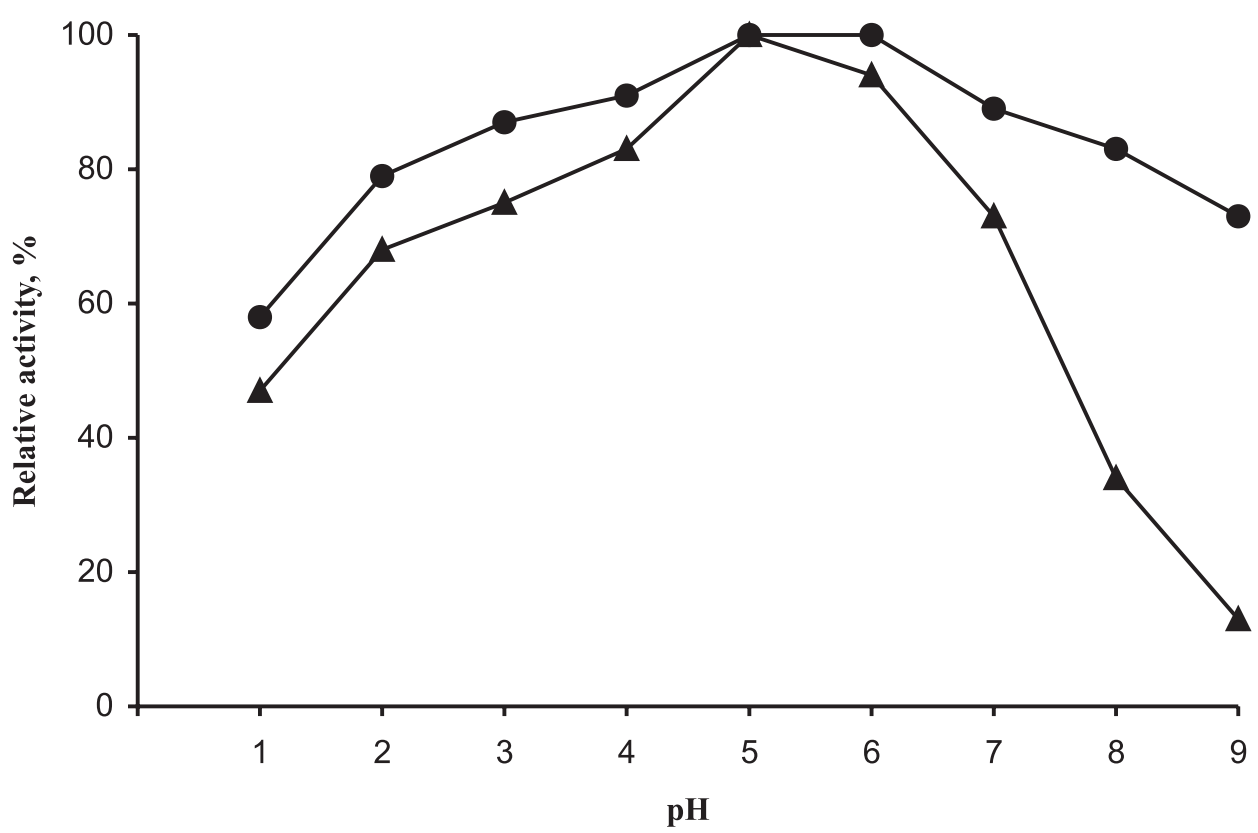

Figure 1. Relative pH optimum $(\boldsymbol{\Delta})$ and stability $(\bullet)$ of $A$. niger phytase. Determination of the optimal $\mathrm{pH}$ and $\mathrm{pH}$ stability of the phytase was carried out as described in material and methods 
Stability of phytase enzyme was also investigated with treatment of saliva and with proteases (a mixture of trypsin and chymotrypsin), which are the main pancreatic and intestinal secretion (Maenz and Classen, 1998), at the different time intervals (Figure 2). After first hour pre-treatment with saliva resulted in lose of enzyme activity about $10 \%$, while treatment with proteases caused about $40 \%$ decrease of activity. However at the end of the incubation about $50 \%$ of the enzyme activity recovered from treatment with saliva and only $20 \%$ of the enzyme activity recovered from treatment with proteases (Figure 2).

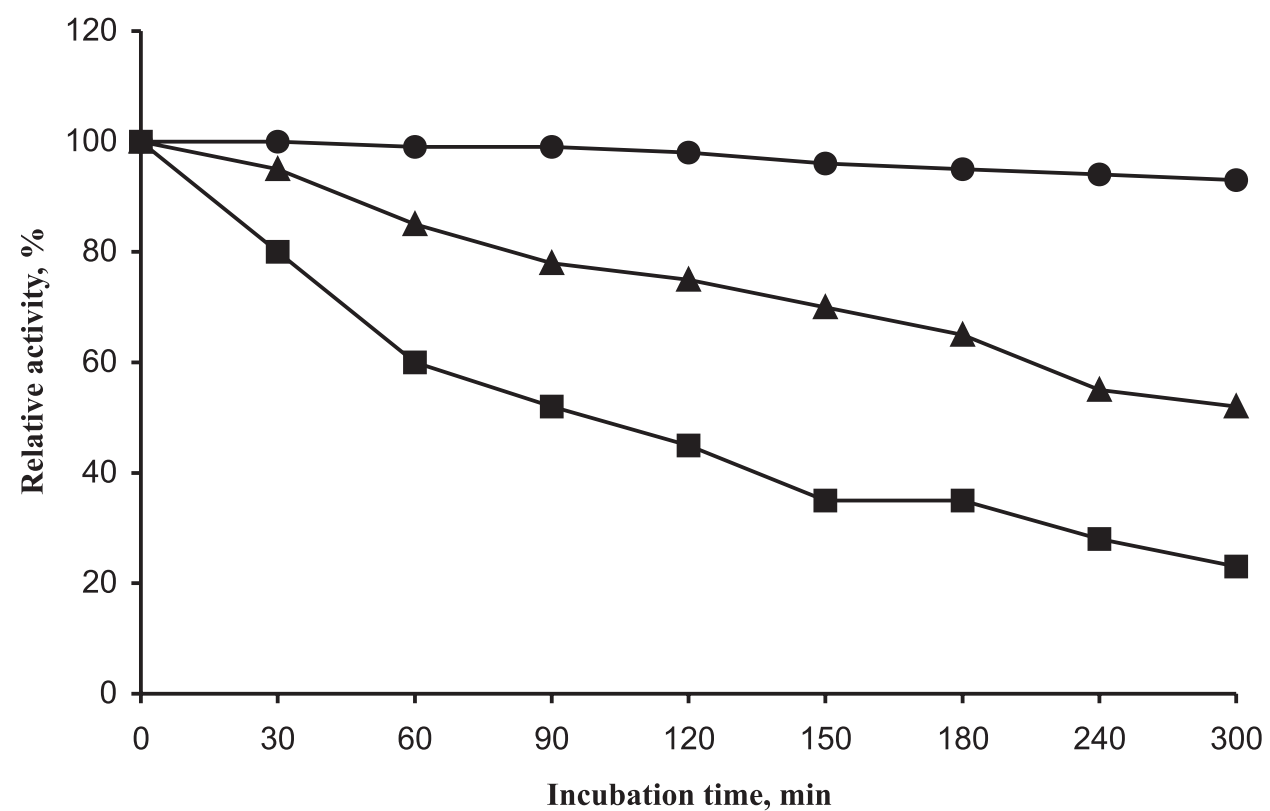

Figure 2. Treatment of phytase enzyme of $A$. niger with saliva $(\mathbf{\Delta})$, proteases $(\boldsymbol{\square})$ and untreated phytase $(\bullet)$. Stability of phytase enzyme was investigated with treatment of saliva and with proteases (a mixture of trypsin and chemotrypsin) at the different time intervals. Saliva was collected randomly from 20 birds before feeding by washing the mouth with $20 \mathrm{ml}$ sterile distilled water then concentrated. The original activity $(100 \%)$ was $9500 \mathrm{U}$

\section{In vitro application of phytase enzyme}

The effects of phytase supplementation on phosphorus utilization of birds are summarized in Table 2. Phosphorus in plasma and tibia increased with increasing of phosphorus amount in the diet $(\mathrm{P}<0.05)$, but phosphorus retained in body remained similar. Addition of phytase enzyme to the low phosphorus containing diets $(0.35 \% \mathrm{P})$ kept the tibia ash content constant. Additions of phytase enzyme to 
the diets did not increase phosphorus retention by body, but increased the availability of phosphorus in diet (Table 2). Percentage of phosphorus retained in body increased when phytase enzyme was used (Table 2). Although the amount of phosphorus and enzyme increased in the diets, the bioavailability of phosphorus was not affected (Table 2).

TABLE 2

Effects of diets to chickens plasma dialysable phosphorus (dP), bone ash retention of phosphorus ${ }^{1}$

\begin{tabular}{ccccccc}
\hline & \multicolumn{5}{c}{ Total phosphorus, tP } \\
\cline { 2 - 7 } Diets & $\begin{array}{c}\text { Intake } \\
\mathrm{g}\end{array}$ & $\begin{array}{c}\text { Excreta } \\
\text { output } \\
\mathrm{g}\end{array}$ & $\begin{array}{c}\text { Apparent } \\
\text { availability } \\
\%\end{array}$ & $\begin{array}{c}\text { Retained P } \\
\text { in body } \\
\text { G }\end{array}$ & $\begin{array}{c}\text { Plasma P } \\
\mathrm{Mg} / \mathrm{dl}\end{array}$ & $\begin{array}{c}\text { Tibia ash } \\
\%\end{array}$ \\
\hline $\mathrm{A}$ & $7.12^{\mathrm{a}}$ & $4.985^{\mathrm{a}}$ & $30^{\mathrm{a}}$ & $2.135^{\mathrm{a}}$ & $3.9^{\mathrm{a}}$ & $49.17^{\mathrm{a}}$ \\
$\mathrm{B}$ & $8.17^{\mathrm{ab}}$ & $5.635^{\mathrm{a}}$ & $31^{\mathrm{a}}$ & $2.535^{\mathrm{b}}$ & $5.2^{\mathrm{ab}}$ & $49.90^{\mathrm{ab}}$ \\
$\mathrm{C}$ & $8.445^{\mathrm{b}}$ & $5.82^{\mathrm{a}}$ & $31^{\mathrm{a}}$ & $2.625^{\mathrm{bc}}$ & $6.5^{\mathrm{bc}}$ & $50.68^{\mathrm{b}}$ \\
$\mathrm{D}$ & $11.235^{\mathrm{c}}$ & $8.655^{\mathrm{b}}$ & $23^{\mathrm{b}}$ & $2.58^{\mathrm{b}}$ & $5.2^{\mathrm{ab}}$ & $49.98^{\mathrm{ab}}$ \\
$\mathrm{E}$ & $11.9^{\mathrm{c}}$ & $9.14^{\mathrm{b}}$ & $23^{\mathrm{b}}$ & $2.76^{\mathrm{bc}}$ & $5.9^{\mathrm{bc}}$ & $50.50^{\mathrm{ab}}$ \\
$\mathrm{F}$ & $12.32^{\mathrm{c}}$ & $9.485^{\mathrm{b}}$ & $23^{\mathrm{b}}$ & $2.835^{\mathrm{c}}$ & $6.7^{\mathrm{bc}}$ & $50.43^{\mathrm{ab}}$ \\
$\mathrm{G}$ & $14.755^{\mathrm{d}}$ & $12.09^{\mathrm{c}}$ & $18^{\mathrm{c}}$ & $2.665^{\mathrm{bc}}$ & $7.05^{\mathrm{c}}$ & $50.57^{\mathrm{ab}}$ \\
$\mathrm{H}$ & $15.555^{\mathrm{d}}$ & $12.715^{\mathrm{c}}$ & $18^{\mathrm{c}}$ & $2.815^{\mathrm{c}}$ & $6.9^{\mathrm{c}}$ & $50.83^{\mathrm{b}}$ \\
$\mathrm{K}$ & $15.895^{\mathrm{d}}$ & $13.08^{\mathrm{c}}$ & $18^{\mathrm{c}}$ & $2.84^{\mathrm{c}}$ & $6.3^{\mathrm{bc}}$ & $50.65^{\mathrm{b}}$ \\
Control & $16.81^{\mathrm{d}}$ & $14.975^{\mathrm{d}}$ & $17^{\mathrm{c}}$ & $2.835^{\mathrm{c}}$ & $7.25^{\mathrm{c}}$ & $50.75^{\mathrm{b}}$ \\
\hline
\end{tabular}

${ }^{1}$ values are means of 2 pens per treatment. Each pen initially contained 14 chicks that were used to obtain all of the above means except tibia ash and plasma dP, for which 4 chicks per pen was used

${ }^{\mathrm{b}}$ means in a column with no common letters $(\mathrm{a}, \mathrm{b}, \mathrm{c}, \mathrm{d})$ are significantly different $(\mathrm{P}<0.05)$

\section{DISCUSSION}

Industrially produced enzymes are increasingly being used as feed additives to improve the nutritional efficiency of farm animals including poultry and swine feed industries (Zyla, 1992; Mroz et al., 1994, Qian et al., 1997). Thus, if dietary enzymes are to be effective as modifiers of fermentation, the enzymes must resist proteolysis and $\mathrm{pH}$ changes. Therefore enzyme, which used as feed additive for poultry must be able to stably maintain its activity in different $\mathrm{pH}$ conditions. Because each part of the digestive tract of the chickens posses different $\mathrm{pH}$ values. The phytase enzyme displayed activity over a wide range of $\mathrm{pH}$ values (Figure 1). Maximum activity was reported at $\mathrm{pH}$ 5.0. From an applied perspective the enzyme displays significant activity over the $\mathrm{pH}$ range encountered in the digestive tract and hence should support degradation of feed derived phytate in the gizzard ( $\mathrm{pH} 4.3-6.3)$, proventriculus $(\mathrm{pH} \mathrm{1-2)}$ and in the small intestine ( $\mathrm{pH}$ 4.0-6.0) (Maenz and Classen, 1998). The phytase enzyme is also stable at low $\mathrm{pH}$ values, retaining full activity after incubation at diffe- 
rent $\mathrm{pH}$ ranging between 1-9 for $6 \mathrm{~h}$ exposure (see Materials and Methods). Although phytase lost approximately $47-13 \%$ of its activity, the enzyme was able to recover full activity at $\mathrm{pH} 5.5$ following $6 \mathrm{~h}$ of exposure at $37^{\circ} \mathrm{C}$ (Figure 1). Stability of the phytase at the different $\mathrm{pH}$ values makes the enzyme the powerful feed additive to improve seed phosphorus utilization in poultry, which has different $\mathrm{pH}$ values in each part of digestive tract. From an applied perspective acid stability is essential if the enzyme is to function/survive in the acidic environment of the digestive tract.

Proteolytic stability of phytase enzyme with treatment of saliva and with proteases resulted in decrease of phytase activity (Figure 2). SDS-PAGE zymogram analysis after treatment of enzyme with saliva and proteases also previously demonstrated loses of the phytase enzyme activity (Ekinci et al., 2000). Stability of phytase to saliva and pancreatic proteases is important for the utilization of cereal phytate. Because more stable enzyme will have great potential for industrial applications. Although in laboratory conditions enzyme lost about $10-80 \%$ its activity, in in vitro experiment showed that remaining enzyme still effective to utilize cereal phosphorus (Table 2). This result gives some idea about the fate of enzyme in digestive track of poultry after taken by animal during the feeding.

As we shown in the laboratory and experiment trails Aspergillus phytase lost about $10-40 \%$ of its activity before becoming effective on utilization of cereal phytate. Most commercial enzyme preparations are the product of fungal fermentation, predominantly by Trichoderma and Aspergillus species, and they consist of a mixture of hydrolytic enzymes. As some of these are used as feed additives in nonruminants, they presumably resist degradation by gastric and pancreatic proteinases. The rate and extent of hydrolysis of individual proteins are affected by their chemical structure: their secondary and tertiary conformation governs their susceptibility to proteases (Shimizu, 1992; Yanke et al., 1998). Therefore chemical structure of Aspergillus phytase should be improved by protein engineering techniques or more active and stable phytases should be investigated such as rumen microorganisms as phytase enzyme sources that are naturally exist in livestock's gastrointestinal tract other than aerobic soil fungi.

The positive effects of phytase supplementation on phosphorus utilization of birds were proved (Table 2). Although the amount of phosphorus and enzyme increased in the diets, the bioavailability of phosphorus was not changed (Table 2). Up to $5 \mathrm{mM}$ phosphorus in diet also has inhibitory effect on phytase activity (Wyss et al., 1999). This might be the reason why phosphorus retention in the body was same even if diet contains more than $0.35 \%$ total phosphorus. Phytase supplementation of broiler diets also improved growth and body weights and decreased mortality (data not shown), which were demonstrated by other researchers as well (Mroz et al., 1994; Qian et al., 1997; Ahmad et al., 2000; Zyla et al., 2001). 


\section{REFERENCES}

Ahmad T., Rasool S., Sarwar M., Haq A.U., Hasan Z.U., 2000. Effect of microbial phytase produced from a fungus Aspergillus niger on bioavailability of phosphorus and calcium in broiler chickens. Anim. Feed Sci. Tech. 83, 103-114

Bae H.D., Yanke L.J., Cheng K.J., Selinger L.B., 1999. A novel staining method for detecting phytase activity. J. Microbiol. Meth. 39, 17-22

Bedford M.R., 2000. Exogenous enzymes in monogastric nutrition; their current value and future benefits. Anim. Feed Sci. Tech. 86, 1-13

Edwards H.M., 1992. 1.25-Dihydroxycholecalciferol supplementation increases natural phytate phoshorus utilization in chickens. J. Nutr. Sci. 123, 567-577

Ekinci M.S., Karaman M., Efe E., Özcan N., Gürbüz Y., 2000. Molecular study on the microbial phytase and its possible application to poultry feed. Reprod. Nutr. Develop. 40, 223-224

Engelen A.J., van der Heeft F.C., Randsdorp P.H., Smit E.L., 1994. Simple and rapid determination of phytase activity. J. AOAC Int. 77, 740-764

Gargova S., Sariyska M., 2003. Effect of culture conditions on the biosynthesis of Aspergillus niger phytase and acid phosphatase. Enzyme Microb. Technol. 32, 231-235

Maenz D.D., Classen H.L., 1998. Phytase activity in the small intestinal brush border membrane of the chicken. Poultry Sci. 77, 557-563

Mitchell D.B., Vogel K., Weimann B.J., Pasamontes L., van Loon A.P.G.M., 1997. The phytase subfamily of histidine acid phosphatases: isolation of genes for two novel phytases from the fungi Aspergillus terreus and Myceliophthora. Microbiology 143, 245-252

Mroz Z., Jongbloed A.W., Kemme P.A., 1994. Apparent digestibility and retention of nutrients bound to phytate complexes as influenced by microbial phytase and feeding regimen in pigs. J. Anim. Sci. 72, 126-132

Mullaney E.J., Daly C., Ullah A.J.H., 2000. Advances in phytase research. Adv. Appl. Microbiol. 47, 157-199

NRC, 1994. Nutrient Requirements of Poultry. National Researh Council. $9^{\text {th }}$ revised Edition. National Academy Press, Washington, DC

Pandey A., Szakacs G., Soccol C.R., Rodriguez-Leon J.A., Soccol V.T., 2001. Production, purification and properties of microbial phytases. Bioresource Technol. 77, 203-214

Qian H., Kornegay E.T., Denbow D.M., 1997. Utilization of phytase phosphorus and calcium as influenced by microbial phytase, cholecalciferol and the calcium: total phosphorus ratio in broiler diets. Poultry Sci. 76, 37-46

Shimizu M., 1992. Purification and characterisation of phytase from Bacillus subtilis (natto) N-77. Biosci. Biotechnol. Biochem. 56, 1266-1269

Van Dijck P.W.M., 1999. Chymosin and phytase made by genetic engineering. J. Biotechnol. 67, 77-80

Wodzinski R.J., Ullah A.H.J., 1996. Phytase. Adv. Appl. Microbiol. 42, 263-303

Wyss M., Brugger R., Kroenberger A., Remy R., Fimbel R., Osterhelt G., Lehmann M., van Loon A.P.G.M., 1999. Biochemical characterization of fungal phytases (myo-inositol hexakisphosphate phosphohydrolases): Catalytic properties. Appl. Environ. Microbiol. 65, 367-373

Yanke L.J., Bae H.D., Selinger L.B., Cheng K-J., 1998. Survey of phytase activity in anaerobic rumen bacteria. Microbiology 144, 1565-1573

Zyla K., 1992, Mould phytases and their application in the food industry. World J. Microbiol. Biotechnol. 8, 467-472

Zyla K., Koreleski J., Swiatkiewicz S., Ledoux D.R., Piironen J., 2001. Influence of supplemental enzymes on the performance and phosphorus excretion of broilers fed wheat-based diets to 6 weeks of age. Anim. Feed Sci. Tech. 89, 113-118 


\section{STRESZCZENIE}

\section{Stabilność fitazy pochodzenia grzybowego, stosowanej jako dodatek do pasz dla drobiu}

Badano wpływ pH oraz enzymu proteazy na stabilność enzymu fitazy, pochodzącego z Aspergillus niger, celem określenia jego przydatności jako dodatku do pasz dla drobiu. Aktywność enzymu obniżała się o 53, 32, 66 i 57\% przy pH 1, 2, 8 i 9, odpowiednio, jednak po uprzednim obniżeniu $\mathrm{pH}$ do 3 przez 6 godz. w temperaturze $37^{\circ} \mathrm{C}$ odzyskiwał on pełną aktywność. Wstępne traktowanie enzymu fitazy przez godzinę śliną spowodowało obniżenie jego aktywności o 10\%, a traktowanie enzymem proteazy o około $40 \%$.

Dodatek fitazy do diety niskofosforowej nie spowodował zmian w zawartości popiołu w kości piszczelowej. Uzupełnienie paszy tym enzymem zwiększyło dostępność fosforu całkowitego, a także poprawiło przyrosty i masę ciała kurcząt oraz obniżyło liczbę upadków ptaków. 
